\title{
El abuso sexual de animales en Argentina
}

\author{
Serra, Juan Ignacio ${ }^{1}$
}

Sumario: I. Introducción. - II. La importancia de las pruebas. - III. La cadena de eventos. - IV. Acción con dolo. - V. Zoofilia y Abuso sexual. - VI. Importancia de una condena por maltrato animal. - VII. Planteo. - VIII. Conclusión

\section{Introducción}

A continuación se analizarán los acontecimientos ocurridos el día 7 de septiembre 2009, por los cuales se condenó a Justo Arancel Tobares por haber hecho ingresar por la fuerza en su domicilio de la localidad de Toay, Provincia de La Pampa, a una perra de raza mestiza, y en ese ámbito de intimidad esquilar el pelo de la misma en la zona genital y realizar maniobras en dicha área, que la lesionaron y le produjeron un sufrimiento innecesario.

El Juez de Instrucción y Correccional de la Ciudad de Santa Rosa, Provincia de la Pampa falló condenando al nombrado Tobares, a la pena de once meses de prisión por considerarlo autor material y penalmente responsable del delito de actos de crueldad contra los animales (artículo 30 inciso 70 en relación con el artículo 10 de la Ley 14.346).

Entendió que queda encuadrado dentro de dicho inciso y artículo de la Ley 14.346, por haber efectuado actos de crueldad con ánimo perverso, provocando un sufrimiento innecesario.

\footnotetext{
${ }_{1}^{1}$ Abogado. Egresado de la Universidad de Buenos Aires. Máster en Derecho Animal y Sociedad de la UAB.
} 


\section{dA derecho ANIMAL la web center de los animales con derecho}

\section{La importancia de las pruebas}

a) Del informe Veterinario:

Según la médica veterinaria que intervino en el caso, la evolución de las lesiones en el animal era de aproximadamente 24 horas. Que la misma no se encontraba en celo, por lo que las lesiones no pudieron haber sido provocadas por otros perros $u$ animales, además de detallar el rapado del pelo en la zona genital, dato que demuestra inequívocamente un accionar humano.

Es de suma importancia contar con informes veterinarios y contemporáneos al hecho acaecido, ya que como especialista en la medicina es el que mejor puede detectar un caso de maltrato y su informe tiene un valor preponderante.

b) De los testigos

Además de un informe médico, los testigos corroboran los hechos y le dan una veracidad. Para el presente, observaron cuando Tobares hacía ingresar a su residencia a la perra, atada con una correa y luego de un tiempo huía del mismo domicilio, y finalmente reconocieron al animal lesionado e inspeccionado como aquel que ingresó en dicho domicilio.

\section{La cadena de eventos}

A partir de la intervención de testigos y médicos especialistas se pudieron fijar los hechos. Si bien no pudo constatarse una penetración sexual sobre el can, se constataron lesiones en ella.

Por tales motivos, no importó si fue realizado con un instrumento o si el imputado realizó dichas actividades, lo importante en el caso se basó, en el daño provocado al animal no humano para lograr entender quién es el culpable de los hechos. 


\section{dA derecho ANIMAL la web center de los animales con derecho}

\section{Acción con dolo}

Por la forma en que fue realizado, se determina la actitud dolosa del acusado.

Los animales reaccionan ante una agresión física y poseen un sentir, dicha circunstancia no podía ser ignorada por Tobares, atento a su relación pasada como domador de caballos.

\section{Zoofilia y Abuso sexual}

El término zoofilia muchas veces se encuentra mal utilizado para describir un acoso sexual contra los animales. Lo que realmente significa es una relación de afinidad, no sexual, entre un humano y animal no humano. A diferencia del simple acto sexual o bestialismo.

El tener relaciones sexuales con un animal siempre es por coerción, ya que no existe la voluntad o consentimiento de la víctima.

En la mayoría de los casos, estos son dañados o hasta se les causa la muerte.

\section{Importancia de una condena por maltrato animal}

Recordar que al tener una pena anterior el cumplimiento puede llegar a ser efectivo. Lo mismo ocurriría en una situación inversa, es lo que sucedería si se tiene una condena condicional por maltrato animal y comete cualquier otro delito.

Si bien se cree que por ser la pena prevista por la ley 14.346 muy baja (quince días a un año de prisión), y el culpable nunca cumpliría pena en prisión, en muchas situaciones esto no es así.

En el presente caso, la defensa de Tobares apeló hasta llegar a la Corte Suprema de Justicia de la Nación Argentina, la cual denegó el recurso extraordinario interpuesto por un requisito formal, por lo que la condena a 11 meses de prisión efectiva que pesaba contra el Señor Tobares quedo firme. 


\section{dA derecho ANIMAL la web center de los animales con derecho}

\section{Planteo}

Sin perjuicio de que en el presente caso se llegó a incriminar a Tobares por el hecho descripto previamente, no fue por el hecho de abusar sexualmente del animal.

Si bien la violación hacia animales no humanos se encuentra repudiada socialmente, dicha circunstancia no esta tipificada.

La justicia debió interpretar la ley de una forma global para no dejar impune al causante de la violación sexual del can. Ya que si las lesiones no hubiesen sido constatadas o la penetración no le hubiese provocado heridas, el agresor se encontraría impune.

Por tales motivos, fue procesado por causar daños innecesarios (art. 1 y 3 inc. 7) al animal de compañía, que no estaba a su cuidado, y no por abuso sexual.

\section{Conclusión}

El vacío legal y la vetustez de nuestra legislación, impidió que sea resuelto el presente caso y similares en la forma adecuada.

Todo ello demuestra la necesidad de reforma de dicha normativa que forma parte de la legislación complementaria del Código Penal de la Nación.

Por lo general estos casos finalizan en un archivo por no constituir delito, ya que nuestra legislación no reprime el abuso sexual dirigido a animales como un delito.

Sin perjuicio de ello, la interpretación dogmática ha llevado a una solución distinta, el Juez realizando una aplicación del concepto de lastimar y causar daño innecesario atribuyó el hecho al ejecutante.

La legislación debe ser modificada con argumentos éticos, científicos y morales con una mayor protección hacia los animales, ya que ellos están en una situación de indefensión frente al bestialismo humano. 


\section{dA derecho ANIMAL}

la web center de los animales con derecho

Finalmente debería no solo estar tipificado esta conducta, sino que también incluir los casos en que alguien promoviere o facilitare, por cualquier medio de intimidación o coerción, el abuso sexual a los animales. 